\title{
Sodium Butyrate and Valproic Acid as Splicing Restoring Agents in Erythroid Cells of $\beta$-Thalassemic Patients
}

\author{
Mahmoud Shekari Khaniani 1,2, Mahdieh Tagizadeh 1,2, Abbasali Hosseinpour Feizi 2,3, Sima Mansoori \\ Derakhshan ${ }^{1,2 *}$ \\ ${ }^{1}$ Hematology and Oncology Research Center, Tabriz University of Medical Sciences, Tabriz, Iran \\ ${ }^{2}$ Department of Medical Genetics, Tabriz University of Medical Sciences, Tabriz, Iran \\ ${ }^{3}$ Department of Pediatrics, Medical Faculty, Tabriz University of Medical Sciences, Tabriz, Iran
}

${ }^{*}$ Corresponding author: Sima Mansoori Derakhshan, Department of Medical Genetics, Tabriz University of Medical Sciences, Tabriz, Iran. Te1/Fax: +984113371587, E-mail: mansooris@tbzmed.ac.ir

Received: February 22, 2015; Revised: November 29, 2015; Accepted: January 27, 2016

Background: $\beta$-Thalassemia is a common autosomal recessive disorder in human caused by a defect in $\beta$-globin chain synthesis. The most common mutations causing $\beta$-Thalassemia have been found to be splicing mutations. Most of which activate aberrant cryptic splicing/sites without complete disruption of normal splicing. IVSI-110 mutation, a common splicing mutation, leads to a $90 \%$ reduction of normal $\beta$-globin synthesis and lead to blood transfusion dependency in the homozygote forms. However, modulation of splicing can be achieved by activation or suppression of transacting factors such as SR (Serine, Arginine) amino acids and hnRNPs (Heterogeneous ribonucleoprotein particle) through drugs.

Objectives: The aim of this study was to investigate the effects of $\mathrm{NaBu}$, isoBu and VPA drugs on restoration of splicing of IVSI-110 $\beta$-Thalassemia pre-mRNA in human.

Materials and Methods: Primary erythroid cells derived from IVSI-110 $\beta$-Thalassemia patients were cultured ex vivo and differentiated in the presence of 0.5 and $1 \mathrm{mM}$ of Na-Butyrate $(\mathrm{NaBu}), 0.5 \mathrm{mM}$ Isobutyramide (isoBu) and $100 \mu \mathrm{M}$ Valproic acid (VPA). RT- PCR analysis was used to evaluate the effect of the drugs in correction of normal splicing in $\beta$ globin mRNAs.

Results: Following treatment with $\mathrm{NaBu}$, isoBu and VPA, the level of normal $\beta$-globin mRNA in Primary erythroid cells derived from IVSI-110 $\beta$-Thalassemia patients, increased 1.7, 1.5, 1.4 fold, respectively relative to normal $\beta$-globin mRNAs. Higher splicing restoration was achieved by $\mathrm{NaBu}$, a histone deacetylase inhibitor, known to upregulate the expression of splicing factors.

Conclusions: The results highlighted the therapeutic potential of splicing modulation for genetic diseases caused by splicing mutations.

Keywords: $\beta$-Thalassemia; IVSI-110 mutation; Splicing modulation; SR proteins

\section{Background}

$\beta$-Thalassemia is a common genetic disease, affecting many around the world. More than 400 mutations play role in the disease that cause deficit and defect in $\beta$ globin in adults. Sever cases of Thalassemia result in manifesting anemia, deformation of bone marrow and splenomegaly that may lead to death in untreated individuals (1). The frequency of $\beta$-Thalassemia is very high in Iran and its distribution is not equal in all regions. The highest frequency is more than $10 \%$ in areas around Persian Gulf and Caspian Sea (2). More than two million carriers of $\beta$-Thalassemia live in Iran (3).

The human $\beta$-globin locus extends over $183 \mathrm{~kb}$ with five functional genes $\left(\varepsilon,{ }^{\mathrm{G}} \gamma,{ }^{\mathrm{A}} \gamma, \delta\right.$ and $\left.\beta\right)$ on the short arm of chromosome 11 in p15.5. The coding region of $\beta$-globin gene in human and other animals is interrupted by two large stretches of non-coding DNA called intervening sequences (IVS) or introns.

Among the mutations in $\beta$-globin, some of the most common are: splicing mutations that exist in intron one and two (4). Generally, normal splice sites are not damaged. Thus, a competition between normal and cryptic splice sites is evident. Accordingly, various amounts of normal and aberrantly spliced mRNAs are being produced. Some of the splicing mutations like IVSI-6 produces a large amount of mRNA with normal splicing, 
which accordingly causes intermedia $\beta$-Thalassemia. However, some of the splicing mutations such as IVS2654 and IVS I-110 decrease the normal splicing of mRNA molecules to a great extent or sometimes even to zero that leads to Major $\beta$-Thalassemia (5).

Splicing is being adjusted through the interaction of many complex splicing factors with various splicing motifs. The main elements of splicing machines are Intronic and Exonic Splicing Enhancers/supressors (ESE/ESS, ISE/ISS). These elements usually interact with serine/arginine-rich (SR) proteins, heterogeneous nuclear ribonucleoproteins (hnRNPs) (with either positive or negative effect), and central splicing machines such as U1 and U2 small nuclear ribonucleoproteins (snRNPs) (6-8). It was shown that gene expression has been restored through splicing pattern related to hnRNPs up to $80 \%$ (9).

Modulation of splicing can be achieved by antisense oligonucleotide, which interacts with sequencespecific splicing motifs (elements) on target RNA. An alternative approach involves activation or suppression of transacting factors such as SR proteins and hnRNPs through drugs. The latter has led to the development of therapeutic approaches using small molecules for modulation of splicing. One such approach involves upregulation of splicing factors to modify splicing, using $\mathrm{NaBu}$, isoBu and VPA, histone deacetylase inhibitors $(9,10)$.

$\mathrm{NaBu}$ has been used to restore normal splicing of cystic fibrosis transmembrane regulator (CFTR) transcripts and resulted in functional improvement in the CFTR channel in cystic-fibrosis-derived epithelial cell line carrying the $3849+10 \mathrm{~kb} \mathrm{C}$ to T splicing mutation (10). It was found that the mechanism by which $\mathrm{NaBu}$ increases the CFTR protein, is though increased expression of splicing factors (SC35 and Htra2-b1).

Chang et al. (2001). reported the first compound Butyrate drug, which could considerably restore splicing defect in spinal mascular atrophy. $\mathrm{NaBu}$ treatment of the transgenic mice model for SMA (Spinal Muscular Atrophy) resulted in an increased expression of survival motor neuron (SMN) protein in the spinal cord and ameliorated neurological symptoms as well as increased acetylation of nuclear histone in neural tissues. The mechanism by which $\mathrm{NaBu}$ affects the SMN protein expression of the SMN2 involves a change in its RNA splicing pattern, which involves the modification of alternative splicing of exon 7 of the SMN2 under the regulation of SR proteins (9-11). In Cystic Fibrosis, sodium butyrate-a histone deacetylase- increases expression of SR (SC35) and SR-like
(Htra2-B1) proteins, splicing factors that increase exon splicing and restore aberrantly spliced mRNA (12-15).

Butyrates are short chain fatty acids that inhibit histone deacetylase and therefore reactivate many genes (16-19). In hemoglobinopathies, Butyrates are clinically used to treat sickle-cell anemia and Thalassemia through induction of the expression of $\gamma$-gene, producing fetal hemoglobin $(\mathrm{HbF})$ and activating the $\gamma$-globin (20-24).

In 2011 Hnilicova et al using splicing-sensitive microarrays, identified about 700 genes whose splicing was altered after treatment with HDAC inhibitor, $\mathrm{NaBu}$. In cultured HeLa and HeLa-GFP-SRp40 cells, they provided evidences that inhibition of HDAC induced acetylation of histone 4 along with an alternatively spliced element occurs. In addition, they showed that HDAC inhibition reduced co-transcriptional association of the splicing regulator SRp40 with the target fibronectin exon (25).

\section{Objectives}

Changing the splicing pattern and recognizing the chemical materials that can increase the level of $\beta$-globin transcript expression is a fundamental stage in treatment of Thalassemia affected by splicing mutations. IVSI-110 mutation is a common mutation in $\beta$ globin gene. In this study, for the first time the effects of $\mathrm{Na} \mathrm{Bu}$, is oBu and VPA on the degree of aberrant splicing of IVSI-110 $\beta$-Thalassemia pre-mRNA were investigated using primary erythroid cells derived from IVSI-110 $\beta$-Thalassemia patients from East Azerbaijan province in Iran. The important novelty of this study is that treatment with these small drugs may increase the levels of $\beta$-globin mRNA and blood hemoglobin, reducing the need for frequent blood transfusion.

\section{Materials and Methods}

In an interventional study, the Human Erythroid progenitor cells were examined to evaluate the effect of the $\mathrm{Na} \mathrm{Bu}$ and VPA on splicing of IVSI-110 $\beta$ Thalassemia pre-mRNA.

\subsection{Human Erythroid Cells}

Three unrelated $\beta$-Thalassemia patients with IVSI110 mutation, including a female and two males (mean age $\leq 8)$ were recruited from northwest Iran. Bone marrow (BM) cells of the individuals were collected in Phosphate Buffered Saline) PBS) medium containing $0.5 \mathrm{~mL}$ heparin. The cells were percipitated at 1500 
rpm for $8 \mathrm{~min}$, treated with $5 \mathrm{~mL}$ of Tris Ammonium Chloride buffer $\left(0.01 \mathrm{M}\right.$ Tris-base, 7.4 g. $\mathrm{L}^{-1} \mathrm{NH}_{4} \mathrm{Cl}$, $\mathrm{pH} 7.2$ ) at $37^{\circ} \mathrm{C}$ for $5 \mathrm{~min}$. The red blood cells were lysed and washed twice with PBS containing penicillin $\left(100 \mathrm{U}^{\mathrm{mL}}{ }^{-1}\right)$ and streptomycin $\left(100 \mu \mathrm{g} \cdot \mathrm{mL}^{-1}\right), 2 \%$ Fetal Bovine Serum (FBS). The purified BM cells were suspended at $2 \times 10^{6}$ cells.mL-1 in Dulbecco's Modified Eagle's Medium (DMEM) Medium (GIB$\mathrm{CO}^{\mathrm{TM}}$, Invitrogen Corporation, Carlsbad, California) containing 30\% FBS, L-glutamine $(200 \mathrm{mM})$, penicillin $\left(100 \mathrm{U} \cdot \mathrm{mL}^{-1}\right)$ and streptomycin $\left(100 \mu \mathrm{g} \cdot \mathrm{mL}^{-1}\right), 2$ U. $\mathrm{mL}^{-1}$ recombinant human erythropoietin (Stem Cell Technologies, Vancouver, Canada), 150 ng. $\mathrm{mL}^{-1}$ human stem cell factor, $1 \mu \mathrm{M}$ Dexamethasone (SigmaAldrich, St. Louis, MO, USA), Bovine Serum Albumin (BSA) 1\% and 2-Mercaptoethanol (1 mM). Erythroid progenitor cells cultured for expansion in $5 \% \mathrm{CO}_{2}$ at $37^{\circ} \mathrm{C}$ at $2 \times 10^{6}$ cells per $1 \mathrm{~mL} /$ well in $24-$ well plates; $30 \%$ of the medium was replaced daily with fresh medium containing all supplements. The cells were cultured for 4 days.

The cells were washed in PBS containing 2\% FBS, containing penicillin (100 U.mL-1) and streptomycin $\left(100 \mu \mathrm{g} . \mathrm{mL}^{-1}\right)$. The cells were transferred to DMEM differentiation media containing 30\% FBS, L-glutamine (200 mM), penicillin (100 U.mL-1) and streptomycin $\left(100 \mu \mathrm{g} . \mathrm{mL}^{-1}\right), 10$ U.mL $\mathrm{m}^{-1}$ recombinant human erythropoietin (rhEPO), 1\% BSA, $1 \mathrm{mM}$ 2-Mercaptoethanol, and $1 \mathrm{mg} \cdot \mathrm{mL}^{-1}$ iron saturated human transferrin. Cells were seeded and maintained at $2 \times 10^{6}$ cells. $\mathrm{mL}^{-1}$. well-1 of a 24-well plate over 1-2 days of culture.

\subsection{NaBu, IsoBu and VPA Administration}

Based on unpublished data drawn from transgenic animal study, 0.5 and $1 \mathrm{mM} \mathrm{NaBu}$ was added. IsoBu and VPA were added at $0.5 \mathrm{mM}$ and $100 \mu \mathrm{M}$, respectively in differentiation media for $24 \mathrm{~h}$ and 48 days after plating of cells. Experiments were repeated 3 times.

\subsection{Reverse Transcriptase-PCR (RT-PCR) Analysis.}

Total RNA was prepared using the Tri-Reagent BD system (Molecular Research Center, Cincinnati, $\mathrm{OH}$ ) as described by the manufacturer's. First-strand complementary DNA (cDNA) was synthesised using a Superscript II reverse transcriptase kit (Invitrogen, Carlsbad, Calif, USA). Primers 5'-CTGAGGAGAAGTCTGCCGTTACT- $3^{\prime}\left(\mathrm{Tm}=60^{\circ} \mathrm{C}\right)$ and $5^{\prime}$-CCTTAGGGTTGCCCATAACAG- $3^{\prime}\left(\mathrm{Tm}=59.3^{\circ} \mathrm{C}\right)$ were used to amplify the sequence between exon 1 and 2 . The $\beta$-actin mRNA was used as an internal control and was amplified with primers $\beta$-actin ( $5^{\prime}$-TCCCTGGAGAAGAGCTACG- $\left.3^{\prime}\right)\left(\mathrm{Tm}=56.54^{\circ} \mathrm{C}\right)$ and $\beta$-actin $\left(5^{\prime}-\right.$ GTAGTTTCGTGGATGCCACA $\left.-3^{\prime}\right)\left(\mathrm{Tm}=58^{\circ} \mathrm{C}\right)$.

To evaluate the effect of the $\mathrm{NaBu}$ on splicing, total RNA was extracted from $\mathrm{NaBu}$-treated erythroid cells on days 1, 2 of differentiation. RT-PCR analysis was performed using the IVSI-110 primers to amplify $\beta$ globin. Meanwhile, $\beta$-actin was used as a loading control in multiplex RT-PCR reaction.

The PCR (Cinnagen CO, Iran) reaction was performed for 1 cycle at $98^{\circ} \mathrm{C}$ for 5 min followed by 30 cycles of $94^{\circ} \mathrm{C}$ for $30 \mathrm{sec}, 55^{\circ} \mathrm{C}$ for $30 \mathrm{sec}$, and at $72^{\circ} \mathrm{C}$ for $45 \mathrm{sec}$, and a final extension at $72^{\circ} \mathrm{C}$ for $5 \mathrm{~min}$. The PCR products were analyzed using 3\% agarose gel. The size of amplified products were $170 \mathrm{bp}$ and a 189 bp from the $\beta$-globin gene, which corresponded to the normal and aberrantly spliced mRNA, respectively.

RT-PCR products of $\beta$-actin, aberrantly and correctly spliced $\beta$-globin were visualized on a $3 \%$ Agarose gel by ethidium bromide staining. Gel scanning with 3D-scanned (BIORAD-imaging system, Life Sciences Inc, USA) and densitometric measurements were carried out with the ONE-Dscan program (Scanalytics, Fairfax, USA). Data analysis was performed using GraphPad Prism software. The relative raw volume amount of each aberrantly and correctly spliced RT-PCR products of $\beta$-globin were normalized individually to that of RT-PCR product of ${ }^{\circ} \mathrm{C}$-actin and presented as mean \pm standard deviation. In order to calculate the fold increase in correctly spliced RT-PCR product, the mean normalized raw volume was divided to that of untreated value.

Ethical consideration: This study was approved by the Regional Committee of Ethics of the Tabriz University of Medical Sciences. Written informed consent was obtained from the all participants.

\section{Results}

4.1. Cumulative Cell Index of IVSI-110 Erythroid Progenitor Cells During the Differentiation Phase Following Treatment with NaBu, IsoBu and VPA

The effects of $\mathrm{NaBu}$, isoBu and VPA on the level of aberrant splicing was investigated in erythroid progenitor cells isolated from IVSI-110 $\beta$-thalassaemic patients. BM-derived erythroid progenitor cells were subjected to a two-phase liquid erythroid cell culture procedure. Following 4 days of erythroid cell expansion, $2 \times 10^{6}$ cultured cells were differentiated in the presence of 0.5 and $1 \mathrm{mM}$ of $\mathrm{NaBu}, 0.5 \mathrm{mM}$ isoBu and $100 \mu \mathrm{M}$ VA. Daily cell-counts revealed that $0.5 \mathrm{mM}$ 
$\mathrm{NaBu}$ was well tolerated, while $1 \mathrm{mM}$ reduced cell proliferation and cell viability relative to untreated cells. VA $(100 \mu \mathrm{M})$ had slightly lower viability compared to $0.5 \mathrm{mM}$ isoBu, and well-tolerated relative to $1 \mathrm{mM} \mathrm{NaBu}$ (Figure 1).

\subsection{Correction of IVSI-110 Pre-mRNA Splicing by} Pharmacologic Agents in Human Erythroid Progenitor Cells

Using gel electrophoresis, two RT-PCR products corresponding to correctly (170 bp) and aberrantly spliced (189 bp) human IVSI-110 $\beta$-globin mRNA were detected (Figure 2). In addition, a single RT-PCR amplification product of the expected size (131 bp) was consistently detected for $\beta$-actin in all reactions, indicating that loading and amplification for each sample was equivalent.

Interestingly, RT-PCR of total RNA isolated $24 \mathrm{~h}$ after treatment, showed that the level of correctly spliced $\beta$-globin mRNA increased in cells treated with $\mathrm{NaBu}, \mathrm{VPA}$ and isoBu. Concomitant decrease has also been observed in aberrantly spliced mRNA (Figures 2 and 3). In the presence of $0.5 \mathrm{mM} \mathrm{NaBu}, 100 \mu \mathrm{M}$ VPA and $0.5 \mathrm{mM}$ isoBu, the level of normal $\beta$-globin RNA increased approximately $1.7 \pm 0.5,1.5 \pm 0.5$ and $1.4 \pm 0.3$ fold relative to untreated cells (Figure 4). These results

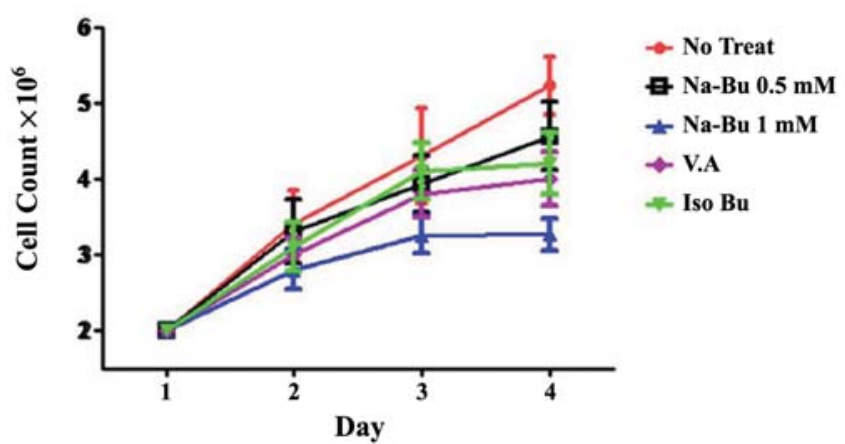

Figure 1. Cumulative index of erythroid progenitor cells during the differentiation phase following treatment with pharmacologic agents showed that, $\mathrm{NaBu}$ driven shift in splicing of human $\beta$ globin pre-mRNA from aberrant to correct in precursor cells from patient IVSI-110 $\beta$-thalassaemic BM was significant.

\section{Discussion}

Many mutations in the $\beta$-Thalassemia diseases are caused by defective splicing of pre-mRNA ${ }^{4}$. A number of these mutations do not alter consensus splice sites or generate missense or nonsense mutations, yet do affect splice site selection (26). IVSI-110 $\beta$-thalassaemia splicing mutation, the effects of $\mathrm{NaBu}$, isoBu and VPA on the level of aberrant splicing was investigated in erythroid progenitor cells isolated from IVSI-110 $\beta$ thalassaemic patients. In this study, we found that administration of $\mathrm{NaBu}, \mathrm{VPA}$ and isoBu to erythroid progenitor cells derived from IVSI-110 $\beta$-thalassaemic patients resulted in the increased amount of wild-type of $\beta$-globin mRNAs 1.7, 1.5 and 1.4 fold respectively relative to normal $\beta$-globin mRNAs in untreated erythroid progenitor cells. This considerable increase of expression level in treated cells is reported in the concentration of $0.5 \mathrm{mM}, 100 \mu \mathrm{M}$ and $0.5 \mathrm{mM}$ from $\mathrm{NaBu}, \mathrm{VPA}$ and isoBu, respectively. These findings may have important implications regarding the treatment of $\beta$-Thalassemia patients.

$\mathrm{NaBu}$ and VPA have been shown to increase the expression of some genes by increasing histone acetylation thereby releasing constraints on the DNA template and reactivating a number of genes (27-31). In the context of haemoglobinopathies, utero infusions of Butyrate, delay the developmental switch off $\gamma$ to $\beta$ globin gene expression in sheep fetuses (32). Sodium

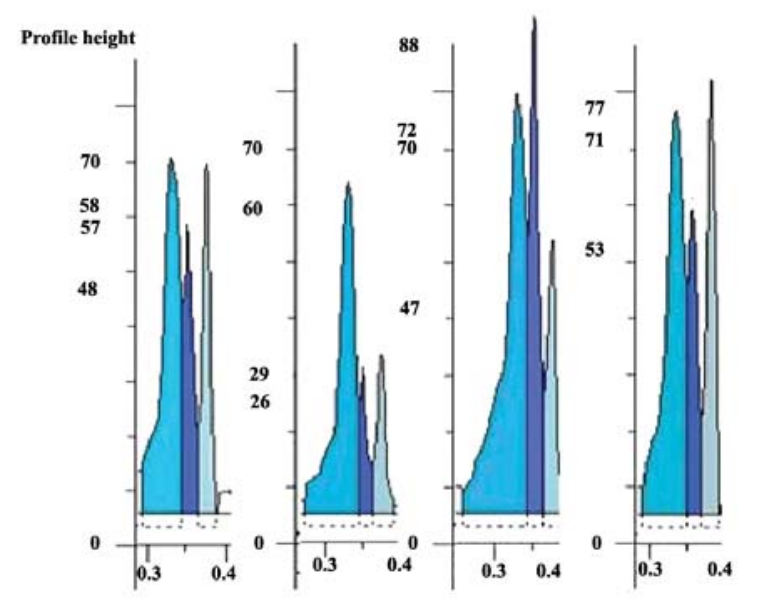

Figure 2. Representative gel electrophoresis (left) and densitometric measurements of RT-PCR analysis (right) of IVSI-110 erythroid progenitor cells treated with $\mathrm{NaBu}$ 


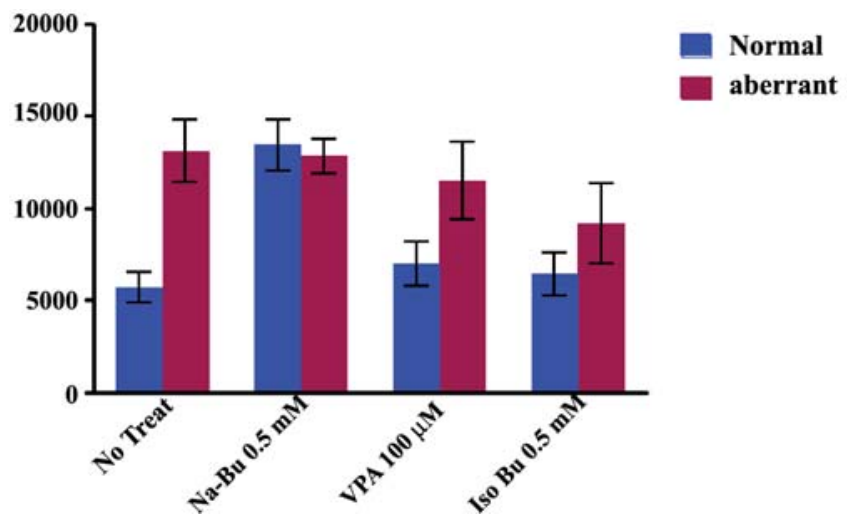

Figure 3. Amount of normal and aberrant $+110 \beta$-globin mRNA in cultured BM cells derived from IVSI-110 thalassemic patients following treatment with $\mathrm{NaBu}, \mathrm{VPA}$ and isoBu

butyrate and similar derivatives increases the expression of fetal-globin genes and are being used clinically in treatment of $\beta$-Thalassemia and sickle cell anemia $(23,24,33)$. These effects of butyrate may occur through the inhibition of histone deacetylase $(30,31)$. In a study carried out by Mallca Nissim-Rafina et al. (2004), it was revealed that administration of $\mathrm{NaBu}$ in cystic fibrosis (CF) increased of Htra2-B1 expression which in turn corrects splicing of CFTR gene in CF. In the case of $\beta$-Thalassemia patients with IVSI-110 mutation, sodium butyrate may acetylate nucleosomal DNA and release other factors such as Htra2-B proteins, which is in the favor of correct splicing in intron 1 of $\beta$-globin gene (34).

Additionally, VPA is a well-known drug confirmed by Food and Drug Administration (FDA) and it has been used for treating epilepsy, bipolar disease, kidney

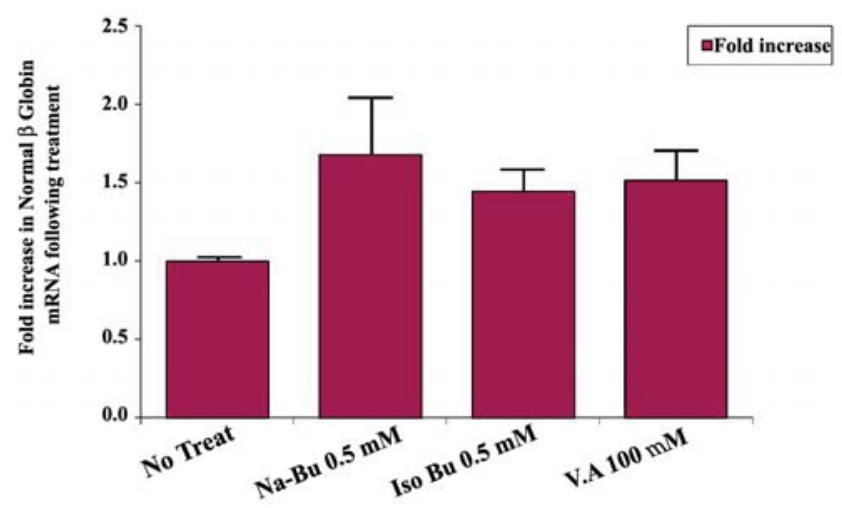

Figure 4. Fold increase of normal $\beta$-globin mRNA in cultured BM cells derived from IVSI-110 thalassemic patients following treatment with $\mathrm{NaBu}$, VPA and isoBu diseases, and migraine in the last three decades(35, 36). Restoring of transcription is among the important effects of the VPA treatment in fibroblast culture of Spinal Muscular Atrophy (SMA) patients $(35,36)$.

This study suggests that, $\beta$-Thalassemia patients with splicing mutations will benefit from $\mathrm{NaBu}$, and VPA drug through two mechanisms: firstly by increasing the $\mathrm{HbF}$ and decreasing the $\alpha$-globin and $\beta$-globin imbalance. Secondly, they will increase normal $\beta$-globin by restoration of splicing in $\beta$-globin gene.

Restoration of $\beta$-globin mRNA to $25 \%$ of the normal level in Thalassaemic patient would have therapeutic potential (37), since heterozygotes with $50 \%$ of haemoglobin are frequently asymptomatic.

Furthermore, $\beta$-globin mRNA and its protein are very stable and mature erythrocytes have a lifespan of about 120 days. Thus, in principle, treatment with $\mathrm{NaBu}$ and VPA may have an extended effect on the in vivo levels of $\beta$-globin mRNA and blood haemoglobin, reducing the need for frequent administration (29). All the findings from $\mathrm{NaBu}$ and VPA treatments in vitro and in vivo indicate that this drug has a high tolerability in tested systems and can increase restored splicing $\beta$-globin transcripts (12). This study showed correction of splicing in human $\beta$-globin pre-mRNA driven from IVSI-110 $\beta$-Thalassaemic patient following treatment with $\mathrm{NaBu}$ and VPA. These findings are promising and will help in treatment of Thalassemia through drugs affecting $\beta$-globin expression. Meanwhile, this approach may potentially be effective in treating many other forms of thalassemia and inherited monogenic disease caused by splicing mutations.

\section{Acknowledgements}

The authors wish to appreciate Hematology Oncology Research Center, Tabriz University of Medical Science for Financial support. The author(s) declare that they have no competing interests.

\section{References}

1. Weatherall DJ CJ. Inherited haemoglobin disorders: an increasing global health problem. Bull World Health Organ. 2001;79:704712.

2. Rahim F AM. Spectrum of $\beta$-Thalassemia mutations in various Ethnic Regions of Iran. Pak J Med Sci Q. 2008;24(3):410415.

3. Suwanmanee T SH, Lacerra G, Svasti S, Kirby S, Walsh CE, Fucharoen S, Kole R. Restoration of human beta-globin gene expression in murine and human IVS2-654 thalassemic erythroid cells by free uptake of antisense oligonucleotides. Mol Pharmacol. 2002:545-553. DOI: 10.1124/mol.62.3.545

4. Weatherall DJaCB. The Thalassemia Syndromes. $4^{\text {th }}$ ed. 
Oxford. Blackwell Science. 2001

5. Wang ZRM, Yeo G, Tung V, Mawson M, Burge CB. Systematic identification and analysis of exonic splicing silencers. Cell 2004; 119:831-845. DOI: http://dx.doi.org/10.1016/j.cell.2004.11.010

6. Maniatis TTB. Alternative pre-mRNA splicing and proteome expansion in metazoans. Nature. 2002;418:236-43. DOI: 10. 1038/418236a

7. DL B. Mechanisms of alternative pre-messenger RNA splicing. Annul Rev Biochem. 2003;72:291-336.

8. Hofmann YLC, Stamm S, Androphy EJ, Wirth B. Htra2-beta 1 stimulates an exonic splicing enhancer and can restore fulllength SMN expression to survival motor neuron 2 (SMN2). Proc Natl Acad Sci USA. 2000;97(17):9618-9623. DOI: 10.1073/pnas.160181697

9. Chang JG H-lH, Jong YJ, Wang NM, Tsai CH-LI H. Treatment of spinal muscular atrophy by sodium butyrate. Proc Natl Acad Sci USA. 2001;98:9808-9813.

10. Nissim-Rafinia M AM, Randell S H, Shushi L, Ozeeri E, ChibaFalek O, Eidelman O, Pollard HB, Yankaskas JR, Keremm B. Restoration of the cystic fibrosis transmembrane conductance regulator function by splicing modulation. EMBO Rep. 2004:1071-1077. DOI: 10.1038/sj.embor.7400273

11. Minamiyama M, Katsuno M, Adachi H, Waza M, Sang C, Kobayashi Y, et al. Sodium butyrate ameliorates phenotypic expression in a transgenic mouse model of spinal and bulbar muscular atrophy. Hum Mol Genet. 2004;13(11):11831192. DOI: $10.1093 / \mathrm{hmg} / \mathrm{ddh} 131$

12. Wirth B. Spinal muscular atrophy: state-of-the-art and therapeutic perspectives. Amyotrophic lateral sclerosis and other motor neuron disorders: official publication of the World Federation of Neurology, Research Group on Motor Neuron. Diseases 2002;3(2):87-95. DOI: 10.1080/146608202760196057

13. Nissim-Rafinia M, Kerem B. Splicing regulation as a potential genetic modifier. Trends in genetics TIG. 2002;18(3):123127. DOI: http://dx.doi.org/10.1016/S0168-9525(01)02619-1

14. Nissim-Rafinia M AM, Randell SH, Shushi L, Ozeri E, ChibaFalek O, Eidelman O, Pollard HB, Yankaskas JR, Kerem B. Restoration of the cystic fibrosis transmembrane conductance regulator function by splicing modulation. EMBO Rep. 2004;5:1071-1077. DOI: 10.1038/sj.embor.7400273

15. Pagani F SC, Zuccato E, Kornblihtt AR, Baralle FE. Promoter architecture modulates CFTR exon 9 skipping. J Biol Chem. 2003;278:1511-1517. DOI: 10.1074/jbc.M209676200

16. Canani RB DCM, Leone L. The epigenetic effects of butyrate:potential therapeutic implications for clinical practice. Clin Epigenet. 2012;4(1):4. DOI: 10.1186/1868-7083-4-4

17. Ma X EH, Diasio RB. Histone deacetylase inhibitors current status and overview of recent clinical trials. Drugs 2009; 69:1911-1934.

18. Wagner JM HB, Lübbert M, Jung M. Histone deacetylase (HDAC) inhibitors in recent clinical trials for cancer therapy. Clin Epigenet. 2010;1:117-1136. DOI:10.2165/11315680000000000-00000

19. Kida YST, Kuwano K. Sodium butyrate up-regulates cathelicidin gene expression via activator protein-1 and histone acetylation at the promoter region in a human lung epithelial cell line, EBC-1. Mol Immunol. 2006;43:1972-1981. DOI: doi.org/10. 1016/j.molimm.2005.11.014
20. Aznarez I, Chan EM, Zielenski J, Blencowe BJ, Tsui LC. Characterization of disease-associated mutations affecting an exonic splicing enhancer and two cryptic splice sites in exon 13 of the cystic fibrosis transmembrane conductance regulator gene. Hum Mol Genet. 2003;12(16):2031-2040. DOI: $10.1093 / \mathrm{hmg} / \mathrm{ddg} 215$

21. Collins AF, Pearson HA, Giardina P, McDonagh KT, Brusilow SW, Dover GJ. Oral sodium phenylbutyrate therapy in homozygous beta thalassemia, a clinical trial. Blood. 1995;85(1):43-49.

22. Singer ST, Kuypers FA, Olivieri NF, Weatherall DJ, Mignacca $\mathrm{R}$, Coates TD, et al. Fetal haemoglobin augmentation in $\mathrm{E} /$ beta $(0)$ thalassaemia: clinical and haematological outcome. Br J Haematol. 2005;131(3):378-388. DOI: 10.1111/j.13652141.2005.05768.x

23. Weinberg RS, Ji X, Sutton M, Perrine S, Galperin Y, Li Q, et al. Butyrate increases the efficiency of translation of gammaglobin mRNA. Blood 2005;105(4):1807-1809. DOI: 10.1182/ blood-2004-02-0454

24. Ginder GD, Whitters MJ, Pohlman JK. Activation of a chicken embryonic globin gene in adult erythroid cells by 5-azacytidine and sodium butyrate. Proc Natl Acad Sci USA. 1984;81(13):3954-3958.

25. Hnilicova J, Hozeifi S, Duskova E, Icha J, Tomankova T, Stanek D. Histone deacetylase activity modulates alternative splicing. PloS One. 2011;6(2):e16727. DOI: 10.1371/journal.pone. 0016727

26. Perrine SP, Swerdlow P, Faller DV, Qin G, Rudolph AM, Reczek J, et al. Butyric acid modulates developmental globin gene switching in man and sheep. Adv Exp Med Biol. 1989;271:177-183. DOI: 10.1007/978-1-4613-0623-8_18

27. Jin Y, Dietz HC, Montgomery RA, Bell WR, McIntosh I, Coller B, et al. Glanzmann thrombasthenia. Cooperation between sequence variants in cis during splice site selection. J Clin Invest. 1996,98(8):1745-1754.

28. Riggs MG, Whittaker RG, Neumann JR, Ingram VM. nButyrate causes histone modification in HeLa and Friend erythroleukaemia cells. Nature 1977;268(5619):462-464. DOI: 10.1038/268462a0

29. Boffa LC, Vidali G, Mann RS, Allfrey VG. Suppression of histone deacetylation in vivo and in vitro by sodium butyrate. $J$ Biol Chem. 1978;253(10):3364-3366.

30. Vidali G BL, Bradbury EM and Allfrey VG. Butyrate suppression of histone deacetylation leads to accumulation of multi acetylated forms of histones $\mathrm{H} 3$ and $\mathrm{H} 4$ and increased DNase I sensitivity of the associated DNA sequences. Proc Natl Acad Sci USA. 1978;75:2239-2243.

31. Sealy L, Chalkley R. The effect of sodium butyrate on histone modification. Cell 1978;14(1):115-1121. DOI: http://dx.doi. org/10.1016/0092-8674(78)90306-9

32. Candido EP, Reeves R, Davie JR. Sodium butyrate inhibits histone deacetylation in cultured cells. Cell. 1978;14(1):105113. DOI: http://dx.doi.org/10.1016/0092-8674(78)90305-7

33. Perrine SP, Rudolph A, Faller DV, Roman C, Cohen RA, Chen SJ, et al. Butyrate infusions in the ovine fetus delay the biologic clock for globin gene switching. Proc Natl Acad Sci USA. 1988;85(22):8540-8542.

34. Kole R, Williams T, Cohen L. RNA modulation, repair and 
remodeling by splice switching oligonucleotides. Acta Biochim Pol. 2004;51(2):373-378.

35. McCaffrey PG, Newsome DA, Fibach E, Yoshida M, Su MS. Induction of gamma-globin by histone deacetylase inhibitors. Blood 1997;90(5):2075-2083.

36. Lacerra G, Sierakowska H, Carestia C, Fucharoen S, Summerton J, Weller D, et al. Restoration of hemoglobin A synthesis in erythroid cells from peripheral blood of thalassemic patients. Proc Natl Acad Sci USA. 2000;97(17):9591-9596. DOI: 10.1073/ pnas. 97.17.9591

37. Sazani P, Kole R. Therapeutic potential of antisense oligonucleotides as modulators of alternative splicing. J Clin Invest. 2003;112(4):481-486. 